Craig Gent

\title{
With our Backs to the Future
}

Craig Gent is a doctoral researcher in the Centre for Interdisciplinary Methodologies at the University of Warwick, UK. His primary research interests are the philosophy of work, autonomous Marxism and digital technology. He can be contacted at C.Gent@warwick. ac.uk.

\section{Abstract}

"The future has been cancelled," declares the 'accelerationist manifesto.' ${ }^{1}$ But where does this lead us? Concepts such as 'time' and 'the future' are almost ineffably broad once given a degree of sustained concentration. In this essay, I look to the relationship between temporality (as our phenomenological experience of what is to come) and historicity (in the sense of the direction of society) in order to question how our perception of temporality in the everyday conditions our perception of the horizon of possibilities which comprise the future, particularly

$1 \quad$ See Nick Srnicek and Alex Williams, "\#ACCELERATE MANIFESTO for an accelerationist politics," Critical Legal Thinking, May 14, 2013, accessed May 18, 2014, http:// criticallegalthinking.com/2013/05/14/accelerate-manifestofor-an-accelerationist-politics/. with regard to conceiving or imagining a future which is non-capitalist.

With our Backs to the Future

"Who controls the past controls the future. Who controls the present controls the past."

George Orwell, Nineteen Eighty-Four

"Who controls the past now controls the future. Who controls the present now?"

Rage Against the Machine, Testify

\section{Introduction}

'Time' is clearly a concept of epic proportions. In the everyday it can be used to refer to the understanding of the monotony of the nine to five or to memorialize a deceased relative. Politically, time can be conceived of in terms of the horizons of possibility or as a tool by which to manage productivity through (post-) Taylorist organization. Time can be thought of as temporality, or the phenomenological grasp we have of the actions around us. Alternatively it can be understood as historicity, or the movement of history. Throughout the canon of critical thought, from Marx to Berardi, the concept of time has been a key area in developing both a critique of the social conditions of capitalism and 
an emancipatory project which hopes to transcend it. This is not without foundation: from the organization of piecemeal work on the Fordist production line to Fukuyama's famous declaration that we have reached

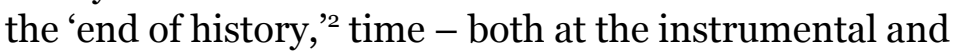
narrative level - is a central terrain upon which modern capitalist production and politics operates. Since entering the current paradigm of neoliberalism, much has been made of the idea that we have lost the future; that it has been forgotten or cancelled. ${ }^{3}$ In the polemic Capitalist Realism: Is There No Alternative?, Mark Fisher starts from Jameson's frequently paraphrased idea that it is now easier to imagine the end of the world than the end of capitalism. ${ }^{4}$ This idea or problem that opponents of capitalism have seized upon opens up a range of issues which need to be unpacked if we are to 'reclaim' the future as the horizon of possibility in any sense: if the future is cancelled, what sort of present do we find ourselves in? What gives us an overwhelming sense of stasis? What is the relationship between temporality, historicity and directionality? And what sort of temporality would a 'critical theory of the future' seek to achieve for us?

I am interested in developing a critique of linear temporality, which I argue is the dominant mode of

2 Francis Fukuyama, The End of History and The Last Man (London: Penguin, 2012)

3 For typical iterations of this sentiment see Srnicek and Williams, "\#ACCELERATE MANIFESTO for an accelerationist politics;" Franco Berardi, After the Future, trans. Arianna Bove et al. (Oakland, CA: AK Press, 2011); Luke Cooper, "Reclaim the future? An idea whose time has come," OpenDemocracy, November 27, 2012, accessed May 18, 2014, http://www. opendemocracy.net/ourkingdom/luke-cooper/reclaim-futureidea-whose-time-has-come; Mark Fisher, Capitalist Realism: Is There No Alternative? (Winchester: Zero Books, 2009).

4 Fisher, Capitalist Realism, 1. temporal perception within neoliberal capitalism. Starting from Simmel's conception of modernity as eternal present, this article will excavate the ways the multiplicity of 'present time' is perceived by us as simultaneously stable and transitory, particularly in the current cultural paradigm of 'precarity.' Arguing that our phenomenological experience of temporality results in a certain comportment towards the world across incumbent political institutions, I will go on to posit what a critical theory of the future might look like. Through an analysis of Benjamin, Deleuze and Derrida I will argue that a considered separation of 'temporality' and 'historicity' is required to regain a sense of the future, along with an approach of what the latter calls 'messianicity without messianism.' In this way I will argue that in order for us to breach our collective incapacity to imagine a postcapitalist historical future, we need to see a cultural shift in the way we live and perceive phenomenological temporalities. Returning to the political themes around accelerationism, lastly I want to suggest that while the key cultural targets of accelerationism (namely work and technology) are indeed of paramount importance, a meaningful attempt to properly expand the horizons of possibility for the future requires a more coordinated engagement with a broader assemblage of terrains in the present.

\section{Modernity as eternal present}

If we accept Benjamin's observation that with each period of social organisation comes a mode of reception and perception, ${ }^{5}$ we must start at the historical root of our current impasse with the idea of modernity. While I have no interest in suggesting any necessity

$5 \quad$ Walter Benjamin, The Work of Art in the Age of Mechanical Reproduction, trans. J. A. Underwood, (London: Penguin Books, 2008), 8. 
or causality in the subsequent development of society since the dawn of modernity, I would like to at least keep in mind that modernity provides a rich ground from which contemporary societal forms have emerged. As David Harvey is keen to note, ${ }^{6}$ Marx identifies that societal and conceptual development across historical epochs is contingent upon shifts and tensions involving myriad factors across a variety of reciprocal terrains: the relationship of man to nature, the processes of production, our relationship to technology, the processes of social reproduction, the production of social relations, mental conceptions of the world $;^{7}$ to which Harvey also points us to a seventh terrain in Marx, our relationship to legal and political superstructures. ${ }^{8}$ I do not think, therefore, that it is sufficient to speak of returning to or reclaiming modernity, since modernity has been a force on all of these terrains, and as such is a constitutive factor in all the socio-political configurations we have seen in the last 250 years right up to the present day. Nor do I think pointing to an 'alternative modernity' goes very far to resolve the original, unresolved political-philosophical tensions and contradictions with modernity, abstraction and rationalization. ${ }^{9}$

Where Srnicek and Williams take aim at neoliberalism for restricting our view of the future, ${ }^{10}$ and I agree in with their target in part, others argue that in fact the

6 David Harvey, A Companion to Marx's Capital, (London: Verso, 2010), 189-201.

7 Karl Marx, Capital: Volume One, trans. Ben Fowkes, (London: Penguin Books, 1976), 493f4.

8 Ibid., $175 \mathrm{f} 35$.

9 Srnicek and Williams, “\#ACCELERATE MANIFESTO;” For a canonical exploration of these contradictions see Theodor W. Adorno and Max Horkheimer, Dialectic of Enlightenment, trans. John Cumming, (London: Verso, 1997).

10 Srnicek and Williams, "\#ACCELERATE MANIFESTO.” phenomenon runs deeper into the essential traits of modernity itself. Benjamin concurs with Simmel's idea that modernity presents a "particular mode of lived experience," arguing that modernity is essentially characterized by a tension between what can be termed 'objective' and 'subjective' culture, which plays itself out in various ways throughout everyday life. ${ }^{11}$ In what could be considered a forebear to Lukács' articulation of reification, ${ }^{12}$ Simmel posits that subjective culturethe qualitative, essential realm which we grasp most primordially-becomes dominated by objective culture. ${ }^{13}$ For Simmel, objective culture is typified by money: it indicates the objectification and calculation of the total, the rationalization of society into 'technical perfection. ${ }^{14}$ As Lukács later articulates, this rationalization strips the subjective of anything which cannot be made calculable, reducing it to an abstract, quantifiable form. ${ }^{15}$ If we consider the temporality of this process of objectification as Simmel presents it, culture appears to move towards the domination of a "final object," 16 or 'objective' perfection in some sense. As such, the temporality of the present appears lineated to us, directed towards the rational society. ${ }^{17}$ As objective culture comes to dominate,

11 David Frisby, Fragments of Modernity: Theories of Modernity in the Work of Simmel, Kracauer and Benjamin, (Cambridge: Polity Press, 1985), 46.

12 See Chapter 4 - "Reification and the Consciousness of the Proletariat" - in Georg Lukács, History and Class Consciousness, trans. Rodney Livingstone, (London: Merlin Press, 1971).

13 Frisby, Fragments of Modernity, 42.

14 See Georg Simmel, "Tendencies in German Life and Thought Since 1870," trans. W. D. Briggs, The International Monthly 5 (1902): 93-111 \& 166-184.

15 Lukács, History and Class Consciousness, 83-7.

16 Frisby, Fragments of Modernity, 42.

17 On this point, Simmel noted the significant rise of the idea of 'social justice' in the 1880s. See ibid., 101. 
it comes to be perceived by us as stable and temporally the present becomes eternalized as constantly immediate through the objective rationalization of time. However the constancy and immediacy of objective culture is at the expense of historic traditional or concrete structures, for objective culture not only eliminates our possibility of an alternative future, but also our ability for the past to imbue the world around us. Just as money is simultaneously stable and transitory, ${ }^{18}$ so is objective culture too. On one hand it appears a sure thing, presenting the reality of all around us as an eternalized present, yet on the other the relationships within it from employment to housing - appear precarious and fleeting. As Frisby states: "If modernity as a distinctive mode of experiencing (social) reality involves seeing society and the social relations within it as (temporally) transitory and (spatially) fleeting then this implies, conversely, that traditional, permanent structures are now absent from human experiences." ${ }^{19}$ For Simmel this phenomenon can be observed in our cultural fixation with fashion, which seeks always the 'recreation' of the immediate present. In this way, it appears to us that no other form of social organization is possible: modernity becomes eternal present, or "supra-temporal. ${ }^{20}$ It should be noted however that this particular mode of reception - modernity as eternal present - is for Simmel a result of a 'mature money economy, ${ }^{21}$ or what we might consider industrial capitalism. It therefore seems clear to me that if we wish to understand our current perception of temporality we must analyse the contemporary forms of social organisation within an advanced neoliberal framework, or what we might call 'late capitalism.'

18 Georg Simmel, The Philosophy of Money, trans. Tom Bottomore and David Frisby, (Abingdon: Routledge, 2011).

19 Frisby, Fragments of Modernity, 45.

20 Ibid., 47.

21 Ibid., 103-4.

\section{Linear temporality in the present}

The theme of the future (implied as post-capitalist) being 'lost,' 'cancelled' or 'forgotten' has been a recurring theme within Marxian and left activist discourses since the global financial crisis of 2008. ${ }^{22}$ The financial collapse called into question issues of accountability, governance and inequality, seemingly going against Fukuyama's proclamation that neoliberalism and liberal democracy marked the 'end of history'. ${ }^{23}$ However, even after this seismic event austerity measures and neoliberal privatization have continued across Europe under the slogan 'there is no alternative.' This presents us with the narrow and linear temporal imaginary that the events of the past which led to the crisis remain in the past, and that austerity measures are a causal effect of that crisis. The political football of 'dealing with the deficit' has been the foremost fixture in British politics since 2009, but of course 'dealing with the systemic causes of the deficit' has not been quite as fashionable. Indeed, 'dealing with the deficit' has been the perfect modus operandi for the continuation and even expansion of neoliberal enterprises such as privatization post-crash. Here we can see the 'stable' and 'transitory' narratives are running simultaneously: while the crisis was transitory, neoliberal capitalism has remained politically stable as an objective constant. Indeed, even grassroots resistance campaigns over the last five years in Europe have centred around a message of simply being 'against austerity': rather than challenge neoliberalism they simply focus

22 See Cooper, "Reclaim the future? An idea whose time has come;" and Nick Srnicek, Alex Williams and Armen Avanessian, "\#Accelerationism: Remembering the Future," Critical Legal Thinking, February 10, 2014, accessed May 18, 2014, http://criticallegalthinking.com/2014/02/10/ accelerationism-remembering-future/.

23 Fukuyama, The End of History and The Last Man. 
- like governments - on growth and progress, but with nostalgic longing for a prior configuration of capitalism, namely post-war social democracy. As Weeks notes, this approach is fundamentally reactive and typifies a politics of ressentiment which looks to a lost past, as opposed to a politics of hope which seeks to regain a lost future. ${ }^{24}$ When Fisher draws upon Jameson's adage that it is now easier to imagine the end of the world than the end of capitalism, ${ }^{25}$ he does so to highlight neoliberalism's triumph is that neoliberal capitalism is now widely perceived to be the only 'realistic' configuration of society. ${ }^{26}$ The 'future' is then organised around narrow augmentations within the capitalist framework such as 'growth' and 'progress', which are purposefully vacuous. While giving the illusion of movement, the orientation towards 'progress' actually leaves us static within a present which is only ever recreated and upon which we are fixated. ${ }^{27}$ Instead of a 'flow' of time, we experience 'present time,' a fundamentally constant form which is only superficially altered. ${ }^{28}$ Although it possesses an internal linear temporality, it is static in that is has no external directionality: like the hamster on the wheel, it is simultaneously linear and forward-facing, yet not actually moving at all. Rather, "it is a movement of time as

24 Kathi Weeks, The Problem With Work: Feminism, Marxism, Antiwork Politics, and Postwork Imaginaries, (Durham, CA: Duke University Press, 2011), 199.

25 Fisher, Capitalist Realism, 2.

26 This is particularly the case since the collapse of the Eastern bloc and the end of state socialism, which at least provided an example of an alternative form of social organization that we could 'realistically' imagine.

27 Moishe Postone, Time, Labor, and Social Domination: A Reinterpretation of Marx's Critical Theory, (Cambridge: Cambridge University Press, 1993), 294.

28 Ibid., 295. opposed to a movement in time." ${ }^{29}$ Therefore there is the sense that issues of the past are not addressed but instead displaced or repressed. Instead of progress representing a learning curve, it resembles a way of forgetting the past which inhibits us from any 'real' directional progression from our situation in the present. Marcuse describes this 'real' progression as 'the break'; a moment that "would open the possibility of an essentially new human reality." 30

The 'present time' upheld by neoliberalism should be understood as rhizomatic, in that temporality as currently perceived is manifested as a multiplicity with various material structures and 'habits' across society rooting us to this certain mode of perception, ${ }^{31}$ conditioning the possibilities and boundaries of our imaginary namely the ability to think and live in non-linear, nonstatic temporalities. Deleuze demonstrates how these habits condition us by recalling Hume's 'famous thesis': "Repetition changes nothing in the object repeated, but does change something in the mind which contemplates it." ${ }^{2}$ 'Habits,' as conceived by Deleuze, should be understood to operate in terms of signs which imbue our understanding and experience of the everyday. ${ }^{33} \mathrm{We}$ can see how signs indicate simultaneous transitory and constant temporalities: every five years the government may change but the parliamentary cycle itself is a given, likewise with each term of the school year the pupil 'moves

29 Ibid., 294.

30 Herbert Marcuse, One-Dimensional Man: Studies in the Ideology of Advanced Industrial Society, (Abingdon: Routledge, 2002), 235.

31 Gilles Deleuze, Difference and Repetition, trans. Paul Patton, (London: Continuum, 2004), 96-101.

32 Ibid., 90.

33 Henry Somers-Hall, Deleuze's Difference and Repetition, (Edinburgh: Edinburgh University Press, 2013), 65. 
forward' but the school always remains a disciplinary institution. Perhaps the most everyday institution is that of work, in which we organize our lives around the work rota. Even with the onset of post-Fordism - marking the dissolution of the formerly-rigid boundaries of the workplace and the erosion of a "stable time structure" 34 - we can enjoy either flexibility or precarity but still our energies must be arranged around the fact of our bills needing to be paid on the $1^{\text {st }}$ of each month. Where once life could be divided between work and our administered "technically available' free time," 35 we have seen the rise of what Standing calls 'tertiary time': time which loses its designation as 'free' in any sense, is limited yet always having demands made upon it which we are then "forced to juggle." ${ }^{36}$ In this sense, the development of abstract time (that is, time as rationalized within a standardized framework) is "closely tied to the 'progress' of capitalism as a form of life." ${ }^{37}$ Therefore we can see that our experiences of the temporal institutions which surround us contract with each other, implicating and conditioning our overall sense of temporality. This forces us to consider our experience of temporality "from the perspective of the demands placed upon it" by the institutions and structures around us. ${ }^{38}$ The content of these structures is intrinsically political: indeed they are the architecture of social organisation. As such they embody certain disciplinary and normalizing strategies

34 Guy Standing, The Precariat: The New Dangerous Class, (London: Bloomsbury, 2011), 119.

35 Marcuse, One-Dimensional Man, 52.

36 Standing, The Precariat, 119.

37 Postone, Time, Labor, and Social Domination, 213.; I do not intend to imply here that there might not have been abstract time before capitalism, and I feel if pushed Postone would concur, however I am choosing to use the idea here in terms of the 'intensification' of time as it makes demands upon us.

38 Standing, The Precariat, 119. which historically correlate with the development of capitalism, ${ }^{39}$ thereby reinforcing the idea of what is 'realistic' and therefore what we expect of the future. Fisher summarizes that "capitalism seamlessly occupies the horizons of the thinkable." ${ }^{40}$

\section{A Critical Theory of the Future?}

Within this paradigm, our demands become limited. In 2011 the UK Trades Union Congress' called for an alternative to austerity centred around 'growth' and a return to full employment, reflecting the commodity pluralism of Pepsi as an alternative to Coke. Berardi states: "When the collective imagination becomes incapable of seeing alternatives, the future becomes a threat." ${ }^{41}$ How then are we to reclaim the future? Against the backdrop of capitalist realism, a critical theory of the future which proposes an emancipatory project must surely draw upon hope, seeking to transcend the limitedness of demands which surrounds us. If - as Derridians would have it - without hope there is despair, can we have hope without a 'goal' for history? ${ }^{42}$ And if we require a goal for history, does this not merely play into the linear narrative of the development towards the rational society? In the wake of the global financial crisis, hope has taken two primary forms. Firstly has been the 'weathering the storm' approach, characterized in the British context by a fixation on 'the retro' and typified by kitsch allusions to prior crises such as the Second World War - the now-ubiquitous 'Keep Calm and Carry

39 Nathan Widder, Reflections on Time and Politics, (University Park, PA: Pennsylvania State University Press, 2008), 159.

40 Fisher, Capitalist Realism, 8.

41 Berardi, After the Future, 59.

42 David C. Hoy, The Time of Our Lives: A Critical History of Temporality, (Cambridge, MA: MIT Press, 2009), 142-3. 
On' mantra of the mythical 'Blitz spirit' being an example - which reinforce the message that neoliberal solutions will pull us through if we only hold tight. In this sense, the hope of the retro recalls a past that did not exist, or "the future of a particular past." ${ }^{43}$ Secondly is nostalgic hope, such as the TUC's 'alternative' harking to bygone days of Keynesian social democracy or Ken Loach's 2013 film intervention The Spirit of ' 45 . These approaches act only to put "all one's hope in the past," ${ }^{44}$ conforming with the idea of only demanding or imagining the 'realistic' on the basis that it existed in the past. Both the stances indicated by nostalgia and 'the retro' fixate on a form of 'wishful thinking': they promise a lifestyle of security which allows us to forget the negative factors which led to this point, instead placating our desire of what we wish will be realized. In concerning themselves with repetition, neither of these ideas properly transcends 'present time.' They are expressions of a temporal comportment which is passive to their historical circumstance ${ }^{45}$ and which do not give us an account of hope with which to reconstruct the future.

At this point it becomes necessary to make a subtle but important distinction between temporality and historicity in relation to the future. Temporality concerns the individual's sense of the time that is ahead, ${ }^{46}$ measured

43 Ibid., 150 .

44 Ibid., 141.

45 The ideas of inauthentic and authentic temporal comportments and their relationship to passivity and activity could reasonably take up an entire research project in their own right, and would indeed be an area for further research on this topic. For Heidegger's original account see Martin Heidegger, Being and Time, trans. Joan Stambaugh, (Albany, NY: State University of New York Press, 2010), §68.

46 Hoy, The Time of Our Lives, 147. and experienced in terms of activity. ${ }^{47}$ This gives us a more phenomenological grasp of time. Historicity differs in that it refers to "a temporality measured by events," 48 that is, our broader conception of history. While the dominant mode of social organization informs our experience of temporality, it is our experience of temporality which conditions our account of historicity, and thereby our expectations of the future. In order to reclaim the future, then, we require a new mode of temporal perception which can challenge the mode of social organization. The subtle distinction between temporality and historicity is noted by Derrida, who posits that we can have the former without the latter but not vice versa. ${ }^{49}$ This distinction has important implications for a consideration of the future. The French language provides two terms for 'the future': le futur and l'avenir. Where le futur indicates that which is predictable or tangible in the commonly ontological sense, l'avenir refers to a possible but unknown future which is bounded by a return to the present..$^{50}$ From an idealist perspective, the accounts of historicity incorporate all history, and can be considered either teleological (developmental) or eschatological (disruptive). Benjamin responds to these accounts through his articulation of messianism and as we will see later, Derrida seeks to undermine both these accounts, as well as Benjamin's brand of messianism, in favour of 'messianicity without messianism'.

Benjamin argues that it is a non-linear account of time which is required to salvage hope from the collapse of idealism, which expresses a linear imaginary of the progression of time towards the rational society, either

47 Postone, Time, Labor, and Social Domination, 211.

48 Ibid.

49 Hoy, The Time of Our Lives, 165.

50 Ibid., 163. 
by development or destruction. ${ }^{51}$ In his 1936 Theses on the Philosophy of History, we are introduced to the temporal metaphor of the Angelus Novus, inspired by the 1920 painting by Paul Klee..$^{2}$ In Angelus Novus, the angel moves away from the fragments and debris of the past with its back to the future. The key idea is that we are not facing the future forwards. It should be noted that going into the future looking backwards does not indicate a reactionary position, but rather "Benjamin's critical attitude derives from thinking that forward-looking, utopian visions often overlook massive injustice in the past and present." ${ }^{3}$ In other words, if we are to place demands on the present which hope for a better future - that is, for a broader horizon of possibilities - we need to account for the inequalities and barbarism of the past which led us to this point. In this sense, we are not so much 'going toward' but 'going away from.' This is a common theme within accelerationism, which places emphasis on understanding and moving away from capitalism rather than ideally constructing communism..$^{54}$ The angel is not moving towards the future in the limited sense of 'progress' that we explored earlier, and neither is it going backward. Hoy asks: "Are we in fact going backward? No, because we are moving away from where we have been, not back to where we were before. The story is still linear. However, it is difficult to say that we are moving forward." ${ }^{55}$ Note here that while the 'story', i.e. our sense of history, is still linear, our temporality is not. Instead, Angelus Novus presents us with a fragmented, disjointed and non-linear temporality instead of a

\footnotetext{
$51 \quad$ Ibid., 142.

52 Walter Benjamin, Illuminations, trans. Harry Zohn, (New York, NY: Schocken, 1968), 257-8.

53 Hoy, The Time of Our Lives, 153.

54 Srnicek and Williams, "\#ACCELERATE MANIFESTO.”

55 Hoy, The Time of Our Lives, 155.
}

smooth, linear transition from past to future. The point is that while temporality is rhizomatic, it can still be directional in terms of historical change..$^{56}$ Benjamin's account therefore denies us a teleology by providing an account whereby the future only comes from "knowing where we've been, not knowing where we're going," 57 acknowledging that "progress has carried with itself certain elements of regression. ${ }^{58}$ While Derrida concurs that we ought to salvage a sense of 'hope,' he rejects the idea of moving nearer to some remote future ideal and criticizes Benjamin's account for being weak and too messianic. ${ }^{59}$ Although we live in the age of democracy, he notes, "there is not yet any democracy worthy of this name. Democracy remains to come: to engender or to regenerate." ${ }^{60}$ Derrida therefore posits the need for 'messianicity without messianism;' that is, an account which does not posit the coming of an actual 'messiah', but one that is only ever 'about to' come. The idea of 'reclaiming the future' is therefore misleading, as the future exists only in relation to the present; indeed a future reached ceases to be a future at all. Instead, Derrida's messianicity eschews idealism while keeping open the "eschatological possibility of an unpredictable, unexpected event that could break into the present at any instant." ${ }^{\prime \prime 1}$ In this way, Derrida allows us a non-linear account of temporality which is directional without being

56 Ibid., 157.

57 Ibid., 155 .

58 Henri Lefebvre, Critique of Everyday Life, Volume One, trans. John Moore, (London: Verso, 2008), 229.

59 It could be argued that this is a harsh criticism from Derrida, given Benjamin's discontent with the Jewish Enlightenment, but this is an area for further research.

60 Jacques Derrida, Rogues: Two Essays on Reason, trans. Pascal-Anne Brault and Michael Naas, (Stanford: Stanford University Press, 2005), 82.

61 Hoy, The Time of Our Lives, 164. 
teleological and permits us hope without succumbing to an idealist account of historicity.

\section{Towards post-capitalism}

How then are we to use this perception of temporality to construct a post-capitalist future? If "the first step towards a new, more hopeful temporality thus requires that we can first wrestle a viable present from the past,"62 then we need to be able to use the past in reimagining our present in order to challenge the institutions of social organisation that inhibit a post-capitalist imaginary. As Benjamin notes, historical knowledge is "nourished by the image of enslaved ancestors rather than that of liberated grandchildren." ${ }^{33}$ Although this is to say our construction of the future has its basis in the past, it is not to say 'history repeats itself:' rather, it is a process of creation which draws upon the past. ${ }^{64}$ The political project relies not on us creating, however, but on us transcending the "strictly defined set of capitalist parameters that themselves never waver." 65 Whereas for Simmel, the dominance of 'objective culture' cannot break from the paradigm of eternal present, accelerationists such as Srnicek and Williams argue instead that the processes of modernity as not intrinsically limiting, but instead that modernity needs to be salvaged from capitalism in order to imagine a post-capitalist world, ${ }^{66}$ precisely through such a process of creation. This necessarily implicates a non-linear temporality. Acknowledging that "the power of capitalist realism derives in part from the

\footnotetext{
62 Weeks, The Problem With Work, 199.

63 Benjamin, Illuminations, 260.

64 Indeed, Deleuze's own use of Nietzsche's 'eternal return' is one such example of creation. See Hoy, The Time of Our Lives, 160.

65 Srnicek and Williams, "\#ACCELERATE MANIFESTO."

66 Srnicek et al., "\#Accelerationism.”
}

way that capitalism subsumes and consumes all previous history," ${ }^{67}$ accelerationism posits that, like Benjamin's Angelus Novus, the past needs to be redeemed and given meaning in order to progress historically. Whereas for example injustices such as the Third Reich could not be understood without consideration of modernity, if we are to understand how those injustices came about in restoring a directional project, we need to challenge institutions such as Potsdamer Platz which seek to forget the past and instead consider the architecture of Auschwitz's gas chambers.

Lefebvre states: "Above all we must demonstrate the breadth and magnificence of the possibilities which are opening out for man; and which are so really possible, so near, so rationally achievable (one the political obstacles are shattered)." ${ }^{68}$ The reconstruction of the future, then, begins in the everyday, and we can understand our domination through time as one such political obstacle. ${ }^{69}$ One such dominant institution which appears to be a current site of contestation - through accelerationist and even green discourses - is work..$^{70}$ Given that the liberation of time has been a key project for postcapitalist projects ${ }^{71}$ it is unsurprising that movements which have sought to construct the future - such as the futurologists of the 1960s - have placed a great emphasis specifically on the end of work. ${ }^{72}$ Simmel's lens of the quantification of objective culture enables us to see that through work our time is managed and individualized

67 Fisher, Capitalist Realism, 4.

68 Lefebvre, Critique of Everyday Life, Volume One, 229.

69 Postone, Time, Labor, and Social Domination, 295.

70 Srnicek and Williams, “\#ACCELERATE MANIFESTO.”

71 Postone, Time, Labor, and Social Domination, 380.

72 Edward Granter, Critical Social Theory and the End of Work, (Farnham: Ashgate, 2009), 99. 
('in your own time', 'on company time'), and indeed the implementation of 'work bells' is indicative of the social rise of abstract time. ${ }^{73}$ However the struggle over the end of work also has political purchase precisely through both our temporal (generally negative) experience of work, but also through our historical relationship to it and its reduction. Weeks argues the end of work is the most important site of struggle for a critical theory of the future, precisely because of its potential as an emancipatory project as well as its 'ever present' critique of the current state of things against mere 'wishful thinking'. She states: "A utopian demand should be recognizable as a possibility grounded in actually existing tendencies. This is not to say that it should be 'realistic' - at least in the sense that the term is deployed in the typical anti-utopian lament about such demands. Rather the point is that it should be concrete rather than abstract." " However, as noted in the early part of this article such terrains as work do not exist separately as realms from other social spheres. Whether it can be said then that work represents the single most important terrain upon which to construct a critical theory of the future is questionable. Existing accelerationist discourse rightly identifies the two-way relationship between work and technology and to some extent our relationship to the environment. However, the assemblage of terrains posed by Marx as the motors for epochal change remains only half-mapped. Just as 'ever present' as work, for example, are social relations between one another that condition our basic intersubjectivity, and the relations of social reproduction which make production possible.

73 Postone, Time, Labor, and Social Domination, 212-3.

74 Weeks, The Problem With Work, 221.

\section{Conclusions}

What can we hope for? Challenging our everyday perceptions of temporality has to start precisely from the architectures of social organization. And if we are to construct a new horizon of possibility, this requires the concrete theoretical construction of a rationallypossible society which is has its roots in the seeds of the present. In each case, we have to be able to account for and give meaning to the past in order to challenge the narrow temporalities which constrain us in the present. The current conversations about the future which are unfolding around the accelerationist school offer a new horizon of possibility to opponents of capitalism. By positing a future that "neoliberalism is inherently unable to generate," 75 but one which is firmly rooted in the realities and possibilities of the present, accelerationism is a contemporary movement which is seeking to challenge the limits of the future that are presently offered to us. Similarly, the fact that work has recently become a site of struggle after years of trade union stagnation although on the grounds of contesting work itself rather than the terms of exploitation - is encouraging from the perspective of challenging the dominant form of social organization. Neither of these sites of movement are necessarily new, by that is not the point. Rather, their repetition is creative and they are able to draw on the past with meaning and construct a future in the present which is entirely directional but not teleological. For accelerationist ideas to be translated into any kind of meaningful project for expanding the horizons of possibilities, however, I would argue that the project of mapping the terrains for change and their relationship between one another is not complete. In particular, I would be keen to see consideration given to the terrain

75 Srnicek et al., "\#Accelerationism.” 
which conditions the possibilities of our ability to work (or not work) and produce, and which comprises the foundation for all architectures of social organization from the workplace to the economy. Social reproduction is central to our capacity to work, to produce and to create and sustain both life and society. Yet, as in Leninist discourses, accelerationism so far seems to privilege production as the focal point of analysis, running the risk of demanding a new epoch without fully understanding the wedge driven between production and reproduction which characterized the birth of the present epoch. But I hope we can continue that conversation in future.

\section{Bibliography}

Adorno, Theodor W., and Max Horkheimer. Dialectic of Enlightenment. Translated by John Cumming. London: Verso, 1997.

Benjamin, Walter. Illuminations. Translated by Harry Zohn. New York, NY: Schocken, 1968.

Benjamin, Walter. The Work of Art in the Age of Mechanical Reproduction. Translated by J. A. Underwood. London: Penguin Books, 2008.

Berardi, Franco. After the Future. Translated by Arianna Bove, Melinda Cooper, Erik Empson, Enrico, Giuseppina Mecchia, Tiziana Terranova. Oakland, CA: AK Press, 2011.

Cooper, Luke. "Reclaim the future? An idea whose time has come." OpenDemocracy, November 27, 2012. Accessed May 18, 2014. http://www.opendemocracy.net/ourkingdom/ luke-cooper/reclaim-future-idea-whose-time-has-come.

Deleuze, Gilles. Difference and Repetition. Translated by Paul Patton. London: Continuum, 2004.

Derrida, Jacques. Rogues: Two Essays on Reason. Translated by Pascal-Anne Brault and Michael Naas. Stanford: Stanford University Press, 2005.

Fisher, Mark. Capitalist Realism: Is There No Alternative? Winchester: Zero Books, 2009.

Frisby, David. Fragments of Modernity: Theories of Modernity in the Work of Simmel, Kracauer and Benjamin. Cambridge: Polity Press, 1985.

Frisby, David, ed. Georg Simmel: Critical Assessments. London: Routledge, 1994.

Fukuyama, Francis. The End of History and The Last Man. London: Penguin, 2012.

Granter, Edward. Critical Social Theory and the End of Work. Farnham: Ashgate, 2009. 
Harvey, David. A Companion to Marx's Capital. London: Verso, 2010.

Heidegger, Martin. Being and Time. Translated by Joan Stambaugh. Albany, NY: State University of New York Press, 2010.

Hoy, David C. The Time of Our Lives: A Critical History of Temporality. Cambridge, MA: MIT Press, 2009.

Jameson, Fredric. "Future City." New Left Review 21 (2003): 65-79. Accessed May 19, 2014. http://newleftreview.org/ II/21/fredric-jameson-future-city.

Lefebvre, Henri. Critique of Everyday Life, Volume One. Translated by John Moore. London: Verso, 2008.

Lukács, Georg. History and Class Consciousness. Translated by Rodney Livingstone. London: Merlin Press, 1971.

Marcuse, Herbert. One-Dimensional Man: Studies in the Ideology of Advanced Industrial Society. Abingdon: Routledge, 2002.

Marx, Karl. Capital: Volume One. Translated by Ben Fowkes. London: Penguin Books, 1976.

O'Brien, Mahon. Heidegger and Authenticity: From Resoluteness to Releasement. London: Bloomsbury, 2011.

Postone, Moishe. Time, Labor, and Social Domination: A Reinterpretation of Marx's Critical Theory. Cambridge: Cambridge University Press, 1993.

Simmel, Georg. "Tendencies in German Life and Thought Since 1870.” Translated by W. D. Briggs. The International Monthly 5 (1902): 93-111 \& 166-184.

Simmel, Georg. The Philosophy of Money. Translated by Tom Bottomore and David Frisby. Abingdon: Routledge, 2011.

Somers-Hall, Henry. Deleuze's Difference and Repetition. Edinburgh: Edinburgh University Press, 2013.
Srnicek, Nick. and Alex Williams. "\#ACCELERATE MANIFESTO for an accelerationist politics.” Critical Legal Thinking, May 14, 2013. Accessed May 18, 2014. http://criticallegalthinking.com/2013/05/14/acceleratemanifesto-for-an-accelerationist-politics/.

Srnicek, Nick, Alex Williams and Armen Avanessian. "\#Accelerationism: Remembering the Future." Critical Legal Thinking, February 10, 2014. Accessed May 18, 2014. http://criticallegalthinking.com/2014/02/10/ accelerationism-remembering-future/.

Standing, Guy. The Precariat: The New Dangerous Class. London: Bloomsbury, 2011.

Weeks, Kathi. The Problem With Work: Feminism, Marxism, Antiwork Politics, and Postwork Imaginaries. Durham, CA: Duke University Press, 2011.

Widder, Nathan. Reflections on Time and Politics. University Park, PA: Pennsylvania State University Press, 2008. 